\title{
TETRAODONTID COLONIZERS IN THE AEGEAN SEA; SECOND RECORD OF THE SPINY BLAASOP, TYLERIUS SPINOSISSIMUS (ACTINOPTERYGII: TETRAODONTIFORMES: TETRAODONTIDAE)
}

\author{
Maria CORSINI-FOKA ${ }^{1 *}$, Panagiotis MARGIES ${ }^{2}$, Gerasimos KONDILATOS ${ }^{1}$, \\ and Panos S. ECONOMIDIS ${ }^{3}$ \\ ${ }^{1}$ Hellenic Centre for Marine Research/Hydrobiological Station of Rhodes, Rhodes, Greece \\ 236 Niriidon Street, 85104 Kremasti (Rhodes), Greece \\ 379 Karakasi Street, 54453 Thessaloniki, Greece
}

Corsini-Foka M., Margies P., Kondilatos G., Economidis P.S. 2010. Tetraodontid colonizers in the Aegean Sea; Second record of the spiny blaasop, Tylerius spinosissimus (Actinopterygii: Tetraodontiformes: Tetraodontidae). Acta Ichthyol. Piscat. 40 (1): 71-74.

\begin{abstract}
A second record of the small Indo-Pacific fish Tylerius spinosissimus (Tetraodontidae) (known as spiny blaasop) was documented at the beginning of 2009 in the waters of Rhodes Island (south-eastern Aegean Sea, Greece). The finding shows the putative establishment of a population of this alien fish in the Mediterranean with a centre the Dodecanese plateau.
\end{abstract}

Keywords: Tylerius spinosissimus, spiny blaasop, Tetraodontidae, non-indigenous fish, Lessepsian migration, Mediterranean

Up to date, seven species belonging to the family Tetraodontidae occur in the Hellenic waters, the only native oceanic puffer, Lagocephalus lagocephalus (L.) and six non-native species - one of the Atlantic origin: blunthead puffer, Sphoeroides pachygaster (Müller et Troschel, 1848) and five of the Indo-Pacific origin: halfsmooth golden pufferfish, Lagocephalus spadiceus (Richardson, 1845); spiny blaasop, Tylerius spinosissimus (Regan, 1908); Suezian pufferfish, Lagocephalus suezensis Clark et Gohar, 1953; silverstripe blaasop, Lagocephalus sceleratus (Gmelin, 1789); and studded pufferfish, Torquigener flavimaculosus Hardy et Randall, 1983. According to CorsiniFoka and Economidis (2007), the last four species are very recent introductions (from 2003 to 2006), while the other two are older colonizers (Ananiadis 1952, Zachariou-Mamalinga and Corsini 1994). In Greek seas, among the 34 non-indigenous fish species distributed along 24 families, Tetraodontidae presents the highest score of species, accounting for the $18 \%$ of the total (Corsini-Foka et al. 2008). The success of tetraodontids in colonizing the Aegean waters could be attributed to a combination of factors, like a particular ability of adaptation to the new ecosystem, overcoming environmental impediments like temperature, salinity, currents, the ability to occupy available and diversified niches, life history strategies and food habits, as already discussed for fish invasions in the
Mediterranean (Golani 1998, Mavruk and Avsar 2008). Furthermore, the feeding strategy of foraging in a group, as observed on $L$. sceleratus in the aquarium facilities of the Hydrobiological Station of Rhodes and in situ, clearly demonstrate the advantage of such behaviour (unpublished data). Anti-predator adaptations of tetraodontids, like inflation of the body and toxicity (Golani et al. 2006a, b) and burrowing habits, such as those observed on T. flavimaculosus by Bilecenoglu (2005) have to be furthermore considered as factors contributing to successful invasion. The evolution of the EMT (Eastern Mediterranean Transient) (Theocharis et al. 2002, Rilov and Galil 2009) and the increase of the Aegean sea water temperature (Theocharis 2008) could have furthermore contributed to the enhancement of their introduction, establishment and spreading, favouring the dispersion of their planktonic eggs and larvae.

Concerning the Mediterranean Sea, tetraodontid fauna is actually represented by ten species, adding to the above: prickly puffer, Ephippion guttiferum (Bennett, 1831); Guinean puffer, Sphoeroides marmoratus (Lowe, 1838); and bandtail puffer, Sphoeroides spengleri (Bloch, 1785) (see: Vacchi et al. 2007).

Currently, the species $L$. suezensis is abundant and T. flavimaculosus has an increasing occurrence in the south-eastern Aegean Sea; L. spadiceus is present also

\footnotetext{
* Correspondence: Dr. Maria Corsini-Foka, Hellenic Centre for Marine Research/Hydrobiological Station of Rhodes. Cos Street, 85100 Rhodes, Greece, phone: (+30) 22410 27308, fax: (+30) 22410 78321, e-mail: mcorsini@hcmr.gr.
} 
Table 1

Morphometric measurements and meristic characters of Tylerius spinosissimus specimen from Rhodes

\begin{tabular}{|c|c|c|}
\hline & Character & Value \\
\hline \multirow{15}{*}{ 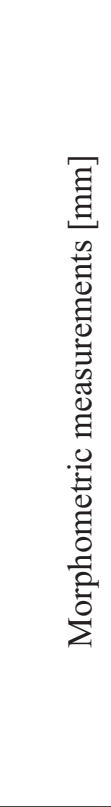 } & Total length & 30.3 \\
\hline & Standard length & 23.3 \\
\hline & Maximum body depth & 10.1 \\
\hline & Caudal peduncle least depth & 1.5 \\
\hline & Caudal peduncle length & 4.4 \\
\hline & Head length & 10.1 \\
\hline & Eye diameter & 3.1 \\
\hline & Preorbital distance & 2.8 \\
\hline & Postorbital distance & 4.2 \\
\hline & Interorbital distance & 3.8 \\
\hline & Dorsal fin length & 4.8 \\
\hline & Anal fin length & 2.4 \\
\hline & Pectoral fin length* & 4.3 \\
\hline & Predorsal length & 16.9 \\
\hline & Preanal length & 17.3 \\
\hline \multirow{4}{*}{ 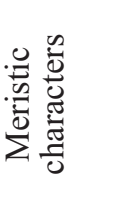 } & Dorsal ray count & 8 \\
\hline & Anal ray count & 6 \\
\hline & Pectoral ray count & 15 \\
\hline & Caudal ray count & 10 \\
\hline
\end{tabular}

* First pectoral fin ray very short, $1.1 \mathrm{~mm}$ in length.

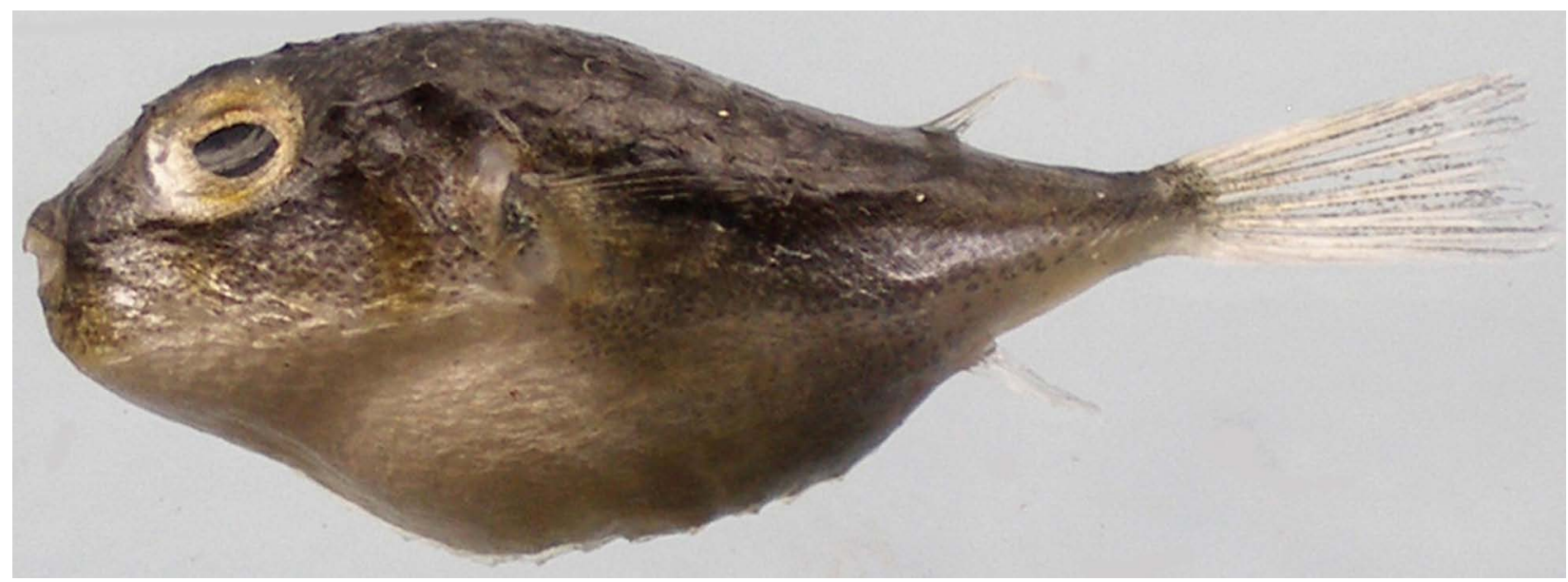

Fig. 1. The defrosted specimen of Tylerius spinosissimus (total length $30.3 \mathrm{~mm}$ ) from Trianda Bay, Rhodes, January 2009

northern, since its first record was from Samos Island This species and the blunthead puffer, S. pachygaster, are (Ananiadis 1952) and recently collected from the Sea of listed among the most successful invasive species in the Marmara (Tuncer et al. 2008), while S. pachygaster is well estab- Mediterranean, negatively affecting biodiversity, fishery lished in the whole Mediterranean (Golani et al. 2002, 2006a), and public health (Streftaris and Zenetos 2006).

the Aegean Sea included (Eryilmaz et al. 2003, Zenetos et al. 2007). On the other hand, the highly toxic L. scelera-

The spiny blaasop, Tylerius spinosissimus, is a tropitus invaded the whole Aegean Sea in a few years (Anonymous 2008) and it shows actually a population explosion in the Levantine coasts (Golani et al. 2007). cal, bathydemersal species (between 250-435 m) in its natural range of distribution, the Indo-West Pacific (Froese and Pauly 2009); it is a small sized tetraodontid, reaching $12 \mathrm{~cm}$ in total length and it has been reported as 
a food item for the bathypelagic species-longnose lancetfish, Alepisaurus ferox Lowe, 1833 (see: Romanov and Zamorov 2007). The species was recorded for the first time in the Mediterranean Sea from the waters of the island of Rhodes (south-eastern Aegean Sea) (Corsini et al. 2005). Since no other specimens have been signalled from the Mediterranean, this occurrence was considered as casual (Pancucci-Papadopoulou et al. 2005, Corsini-Foka and Economidis 2007). However, on 20 January 2009, another specimen, $30.3 \mathrm{~mm}$ in total length, was collected in the bay of Trianda, NW coast of Rhodes Island, in a sandymuddy bottom, at a depth between 50 and $80 \mathrm{~m}$, at the same location reported by Corsini et al. (2005). The collection was performed by boat seining (also named Danish seining) (Jennings et al. 2007), a common method operating in Hellenic coastal fishery (Adamidou 2007). The specimen was identified following Smith and Heemstra (1986) and Matsuura (2001) and had the following meristics: dorsal fin rays 8 , anal fin rays 6 , pectoral fin rays 15 , caudal fin rays 10 . The above counts, along with the measurements of morphometric characters, appear in Table 1. Morphometrics were: standard length 1.3 (in total length); head length 2.3; predorsal distance 1.4; preanal distance 1.4 (all three above in standard length); caudal peduncle least depth 6.7; caudal peduncle length 2.3; eye diameter 3.3; preorbital distance 3.6; postorbital distance 2.4 (all five above in head length). Body features and colour as in previous description (Corsini et al. 2005) (Fig. 1). The fresh specimen was not inflated and the spines on the body were not evident; being the back dark and the belly whitish, it is easy to be confused with L. sceleratus or L. suezensis. The sample, fixed in $70 \%$ ethanol, has been preserved at the Hydrobiological Station of Rhodes collection (Catalogue number HSR-F45).

The species is grouped among the Lessepsian immigrants, the up to now two records showing an ability to colonize shallower niches. This unforeseen new habitat could indicate that a certain population might already be established along the Levantine coasts, but probably undetected or neglected because of the very small size of this fish (Corsini et al. 2005, Corsini-Foka and Economidis 2007). Assuming that propagules of T. spinosissimus are pelagic like in co-familiar species (cf. Golani et al. 2006b, Froese and Pauly 2009), the occurrence of this tetraodontid at the Rhodes marine area may be explained by the counter-clockwise circulation in the Levantine basin which seems to be the main factor for the propagation of Lessepsian species with pelagic propagules to the northern coasts, as discussed in Ben Rais Lasram et al. (2008). However, there are no other records from the Mediterranean, and the two currently known are exactly from the same place in the coasts of Rhodes, far from the Suez Canal. As previously discussed (CorsiniFoka and Economidis 2007), this fact could suggest that other vectors different from usual pathways, like ship ballast, aquaculture or aquaria purposes transport, have probably to be evaluated for the introduction of this fish, as observed for other taxa in Greek waters (Pancucci-
Papadopoulou et al. 2005, Anonymous 2008). Although ship-mediated fish introduction is very rare in the Mediterranean Sea (Ben Rais Lasram et al. 2008), this type of vector was recently suspected for the occurrence of an alien fish-Champsodon nudivittis (Ogilby, 1895) at Iskenderun Bay, Turkey (Çiçek and Bilecenoglu 2009).

The second finding of the spiny pufferfish at Rhodes, six years after the first record, places $T$. spinosissimus among the alien species of the Mediterranean, i.e., species sighted no more than twice so far, as proposed by Golani et al. (2006a) and suggests that its occurrence has no more to be considered casual in the whole basin.

\section{REFERENCES}

Adamidou A. 2007. Commercial fishing gears and methods used in Hellas. Pp. 118-131. In: Papaconstantinou C., Zenetos A., Vassilopoulou V., Tserpes G. (eds.) State of Hellenic Fisheries, SoHelFi. HCMR Publications, Athens.

Ananiadis C. 1952. On the appearance of the fish Tetrodon spadiceus (Rich.) in Greek seas. Praktika of Hellenic Hydrobiological Institute 6 (1): 73-74.

Anonymous 2008. ELNAIS-Ellenic Network Aquatic Invasive Species. version (02/2009) https://services.ath.hcmr.gr.

Ben Rais Lasram F., Tomasini J.A., Guilhaumon F., Romdhane M.S., Do Chi T., Mouillot D. 2008. Ecological correlates of dispersal success of Lessepsian fishes. Marine Ecology Progress Series 363: 273-286.

DOI: $10.3354 / \mathrm{meps} 07474$.

Bilecenoglu M. 2005. Observation on the burrowing behaviour of the dwarf blaasop, Torquigener flavimaculosus (Osteichthyes: Tetraodontidae) along the coast of Fethiye, Turkey. Zoology in the Middle East 35: 29-34.

Corsini M., Margies P., Kondilatos G., Economidis P.S. 2005. Lessepsian migration in Aegean Sea: Tylerius spinosissimus (Pisces, Tetraodontidae) new for the Mediterranean, and six more fish records from Rhodes. Cybium 29 (4): 347-354.

Corsini-Foka M., Economidis P.S. 2007. Allochthonous and vagrant ichthyofauna in Hellenic marine and estuarine waters. Mediterranean Marine Science 8 (1): 67-89.

Corsini-Foka M., Kalogirou S., Economidis P.S. 2008. Marine and estuarine alien fishes in Greece. P. 33. In: Gherardi F., Aquilini L. (eds.) International Conference "Managing alien species for suitable development of aquaculture and fisheries", Florence, Italy, 5-8 November 2008, Abstract Book.

Çiçek E., Bilecenoglu M. 2009. A new alien fish in the Mediterranean Sea: Champsodon nudivittis (Actinopterygii: Perciformes: Champsodontidae). Acta Ichthyologica et Piscatoria 39: 67-69. DOI: 10.3750/AIP2009.39.1.14.

Eryilmaz L., Özulug M., Meriç N. 2003. The Smooth Pufferfish, Sphoeroides pachygaster (Müller and Troschel, 1848) (Teleostei: Tetraodontidae), new to the Northern Aegean Sea. Zoology in the Middle East 28: 125-126.

Froese R., Pauly D. (eds.) 2009. FishBase. [version 01/2009] http://www.fishbase.org.

Golani D. 1998. Impact of Red Sea Fish Migrants through the Suez Canal on the Aquatic Environment of the Eastern 
Mediterranean. Yale University School of Forestry and Environmental Studies Bulletin 103: 375-387.

Golani D., Orsi-Relini L., Massutí E., Quignard J.-P. 2002. CIESM Atlas of Exotic Species in the Mediterranean. Vol. 1. Fishes. Briand F. (ed.), CIESM Publishers, Monaco.

Golani D., Orsi-Relini L., Massutí E., Quignard J.-P. 2006a. CIESM Atlas of Exotic fishes in the Mediterranean. http://www.ciesm.org/atlas/ visited on June 2009.

Golani D., Orsi-Relini L., Massutí E., Quignard J.-P., Dulčić J. 2007. Fish invasion of the Mediterranean-Retrospective and prospective. Rapport de la Commission internationale pour la Mer Méditerranée 38: 10.

Golani D., Öztürk B., Başusta N. 2006b. Fishes of the Eastern Mediterranean. Turkish Marine Research Foundation, Istanbul.

Jennings S., Kaiser M.J., Reynolds J.D. 2007. Marine fisheries ecology. Blackwell publishing, Oxford.

Matsuura K. 2001. Tetraodontidae. Puffers. Pp. 3954-3957. In: Carpenter K.E., Niem V. (eds.) FAO species identification guide for fishery purposes. The living marine resources of the Western Central Pacific. Vol. 6. Bony fishes part 4 (Labridae to Latimeriidae), estuarine crocodiles. FAO, Rome.

Mavruk S., Avsar D. 2008. Non-native fishes in the Mediterranean from the Red Sea, by way of the Suez Canal. Reviews in Fish Biology and Fisheries 18: 251-262. DOI: 10.1007/s11160-007-9073-7.

Pancucci-Papadopoulou M.A., Zenetos A., Corsini-Foka M., Politou Ch. 2005. Update of marine alien species in Hellenic waters. Mediterranean Marine Science 6 (2): $147-158$.

Rilov G., Galil B. 2009. Marine bioinvasion in the Mediterranean Sea-History, Distribution and ecology. Pp. 549-575. In: Rilov G., Crooks J.A. (eds.) Biological invasions in marine ecosystems. Springer-Verlag, Berlin.

Romanov E.V., Zamorov V.V. 2007. Regional feeding patterns of the longnose lancetfish (Alepisaurus ferox Lowe, 1833) of the Western Indian Ocean. Western Indian Ocean Journal of Marine Science 6 (1): 37-56.

Smith M.M., Heemstra P.C. 1986. Tetraodontidae. Pp. 894-903. In: Smith M.M., Heemstra P.C. (eds.) Smiths' sea fishes. Springer-Verlag, Berlin.
Streftaris N., Zenetos A. 2006. Alien marine species in the Mediterranean-the 100 "Worst Invasives" and their impact. Mediterranean Marine Science 7 (1): 87-118.

Theocharis A. 2008. Do we expect significant changes in the thermohaline circulation in the Mediterranean in relation to observed surface layers warming? Pp. 25-29. In: Briand F. (ed.) Climate warming and related changes in Mediterranean marine biota. CIESM Workshop Monographs No. 35, Monaco.

Theocharis A., Klein B., Nittis K., Roether W. 2002. Evolution and status of the Eastern Mediterranean Transient (1997-1999). Journal of Marine Systems 33-34 (1): 91-116. DOI: 10.1016/S0924-7963(02)00054-4.

Tuncer S., Aslan Cihangir H., Bilecenoglu M. 2008. First record of the Lessepsian migrant Lagocephalus spadiceus (Tetraodontidae) in the Sea of Marmara. Cybium 32 (4): 347-348.

Vacchi M., Bussotti S., Miglietta A.M., Guidetti P. 2007. Presence of the Guinean puffer Sphoeroides marmoratus (Lowe, 1838) in the Mediterranean Sea. Journal of Fish Biology 71 (4): 1215-1219. DOI: 10.1111/j.1095-8649.2007.01578.x.

Zachariou-Mamalinga H., Corsini M. 1994. The occurrence of the fish Sphoeroides pachygaster in the south-eastern Aegean Sea (Greece). Annales Musei Goulandris 9: 479-483.

Zenetos A., Vassilopoulou V., Salomidi M., Poursanidis D. 2007. Additions to the marine alien fauna of Greek waters (2007 update). Journal of the Marine Biology Association JMBA2, Biodiversity records, n. 5928. DOI: $10.1017 / \mathrm{S} 1755267207009281$, http://www.mba.ac.uk/jmba//jmba2biodiversityrecords.php.

Received: 24 February 2009 Accepted: 9 July 2009 Published electronically: 25 June 2010 